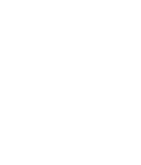
ANNUAL Further
REVIEWS

Click here for quick links to Annual Reviews content online, including:

- Other articles in this volume

- Top cited articles

- Top downloaded articles

- Our comprehensive search

Annu. Rev. Sociol. 2013. 39:171-92

First published online as a Review in Advance on May 22, 2013

The Annual Review of Sociology is online at http://soc.annualreviews.org

This article's doi:

10.1146/annurev-soc-071811-145526

Copyright (c) 2013 by Annual Reviews. All rights reserved

\section{Sociology of Fashion: Order and Change}

\section{Patrik Aspers ${ }^{1,2}$ and Frédéric Godart ${ }^{3}$}

\author{
${ }^{1}$ Department of Sociology, Uppsala University, SE-751 26 Uppsala, Sweden \\ ${ }^{2}$ Swedish School of Textiles, University of Borås, SE-501 90 Borås, Sweden; \\ email: patrik.aspers@soc.uu.se \\ ${ }^{3}$ Organisational Behaviour Department, INSEAD, 77305 Fontainebleau, France; \\ email: frederic.godart@insead.edu
}

\section{Keywords}

diffusion, distinction, identity, imitation, structure

\begin{abstract}
In this article, we synthesize and analyze sociological understanding of fashion, with the main part of the review devoted to classical and recent sociological work. To further the development of this largely interdisciplinary field, we also highlight the key points of research in other disciplines. We define fashion as an unplanned process of recurrent change against a backdrop of order in the public realm. We clarify this definition after tracing fashion's origins and history. As a social phenomenon, fashion has been culturally and economically significant since the dawn of Modernity and has increased in importance with the emergence of mass markets, in terms of both production and consumption. Most research on this topic is concerned with dress, but we argue that there are no domain restrictions that should constrain fashion theories. We identify venues around which sociologists could develop further research in this field.
\end{abstract}




\section{INTRODUCTION}

Fashion is both a significant sociological topic and a social phenomenon par excellence. As a sociological topic, fashion lies at the crossroads of several core subject matters of the discipline (Crane 2000, Kawamura 2005), including collective and personal identity dynamics, production and consumption patterns, and social distinction and imitation mechanisms. Hardly any area of contemporary social life is not subject to fashion, and it is a topic in which all classical sociological questions reappear, from the culture/structure conundrum to the micro/macro debate. We argue that the increased interest in fashion (see, for example, Giusti 2009, White \& Griffiths 2000) should be acknowledged as a sign of both its importance and its generality. And sociologists are well equipped with theory and research tools to understand and explain this phenomenon.

The fast-paced change patterns and easily observable mutations of fashion have led Bell (1976, p. 17) to observe, "In sociological studies fashion plays the role which has been allotted to Drosophila, the fruit fly, in the science of genetics." As a social phenomenon worthy of socialscientific enquiry, fashion spreads far beyond sociology to adjacent disciplines such as history, philosophy, economics, geography, and cultural studies-which in turn influence sociology: "The 'mystery' of fashion changes has fascinated not only economists and sociologists, social historians and cultural anthropologists, but also philosophers and moralists, poets, playwrights, and novelists" (Gregory 1947, p. 148).

However, there is much confusion about what fashion actually is. As explained by Kawamura (2011), this confusion is due primarily to the two meanings of the word-fashion as change and fashion as dress. To be thoroughly studied, fashion needs to be clearly defined, and a clear definition is still lacking. Furthermore, fashion research is haunted by "academic devaluation" (Kawamura 2011). Many reasons have been advanced to explain this situation. Crane \& Bovone (2006, p. 320), for example, explain that fashion, like consumption, is devaluated in academia because it is sometimes seen as a "capitalist manipulation of the public" and is associated "with women's pursuits." Similarly, Kawamura (2005, p. 9) explains that fashion is academically devaluated because it is "linked with outward appearance and women."

Despite these difficulties, many sociologists have addressed fashion since the birth of the discipline. Classical works, for example of Simmel (1904 [1957]) and Blumer (1969), still play a central role. Blumer (1969, p. 290) asked sociologists to "take fashion seriously and give it the attention and study which it deserves." Over the past 15 years, a new generation of sociologists has paid heed to his call and shown great interest in this topic, highlighting the difficulties of theorizing in fashion studies (Tseëlon 2009) and calling for more of this type of work (Quemin \& Lévy 2011). White \& Griffiths (2000, p. 1) showed enthusiasm for the changing context: "The history and theory of fashion has ... become a field of unprecedented academic interest." Fashion, we argue, is still largely a conundrum, but renewed interest opens up relevant venues for research. We foresee that a consolidation of the theoretical and empirical understanding of fashion would allow us to apply this knowledge to numerous social processes far beyond the current domain of application.

In sum, research on fashion is in need of two interrelated developments: a clear definition and more academic legitimacy. The first aim of this article is to review the field of fashion as a sociological topic, with a focus on fashion as change. This focus allows us to offer a definition of fashion that is derived from the review of the literature and to clarify its underlying mechanisms. It also helps identify the type of research that remains to be done. The second aim is to provide accrued legitimacy to the study of fashion. This is why we trace the origins of the field to its classical roots. We update classical theories with a focus on the revival of the field that has occurred in the past few years. Importantly, although fashion as clothing and dress constitutes a valuable setting in which to study fashion as change, on which we focus, we 
suggest that sociologists would gain from using a more developed theory of fashion in which the two concepts would not be confounded.

We have organized this article as follows. We begin by briefly presenting the origins and history of fashion. This enables us to relate fashion to a few other concepts, and thus to clarify what it is not. We then turn to some academic disciplines related to sociology in which the topic has been studied, first, to integrate knowledge; second, to show how more recent findings on fashion in other social sciences could be integrated into sociology; and third, to outline what a specifically sociological perspective on this topic would entail. The rest of the article consists of a review of sociological studies on fashion. Taking an international perspective, we start by exploring the roots of fashion theory in order to find core elements that can constitute a sociological understanding of the concept, and then move on to the more contemporary approaches, comparing and contrasting production and consumption perspectives. Toward the end of the article, we suggest a definition of fashion that synthesizes research on this topic and that could serve as a stepping stone for further theoretical and empirical developments.

\section{THE ORIGINS AND EVOLUTION OF FASHION}

\section{Etymology and Relationship with Selected Concepts}

It is revealing to look at the etymology of the word fashion in a few languages beyond English, such as French (mode), Italian and Spanish (moda), or German (Mode). All these terms have Latin origins. In English, fashion comes from the old (twelfth century) French word façon, which designates ways of making and doing things, highlighting the active role of fashion (Kawamura 2005, p. 3). It also has social connotations, given that the Latin word from which façon is derived (factio) refers to making and doing things together. In the sixteenth century, fashion acquired a more contemporary meaning (Luhmann 2000, p. 47): The concept began to mean conforming to prevailing tastes and to imply an idea of change. Mode and moda come from the Latin word modus and refer to manners; there is also a strong connection to the concepts of modern and modernity. These concepts in turn refer to capitalism, which historically emerged with Modernity (see Breward \& Evans 2005, pp. 1-7). Both etymologies relate to ways of making and doing things, and thus to a diversity of practices (Godart 2012, p. 27). Moreover, at least in English, the etymology of fashion refers to collectives. Only gradually and later did these terms refer to change as explained by Luhmann (2000).

As noted by Welters \& Lillethun (2007, p. xxv), "the definition of fashion is contested." Additionally, a set of concepts are related to fashion and share some of its features but do not fully exhaust its specificity. This lack of clarity does not facilitate research. To make the concept clear, we suggest distinguishing the concept of fashion proper from selected related concepts: fad, innovation, style, and trend.

Fads (or crazes) (Barber \& Lobel 1952, Sproles \& Burns 1994) refer to sudden changes that often spread quickly and fade away rapidly. Fashion differs from fads in two ways: First, although fashions are related in some ways to previous fashions (Belleau 1987), fads appear to be random and impossible to predict. Second, whereas fashions are intrinsically limited in their diffusion because they are driven by distinction, fads are not restricted by the number of people following them because individuals do not use fads to distinguish themselves.

Fashion, moreover, is different from innovation (Gronow 2009). Both fashions and innovations refer to change, and they replace or complement something that already exists - an older way of dressing or an obsolete technology—with something new. However, compared with fashion, innovation alters social practices in a deeper way and has longer-lasting effects. Furthermore, change in fashion does not necessarily imply improvement, whereas it does for innovation. As soon as there is a standard against which change can be evaluated 
independently of taste or preferences, it is better to speak of innovation.

Fashion is also different from style. Welters \& Lillethun (2007, p. xxv) explain, for example, that a style in dress is a "combination of silhouette, construction, fabric, and details that exists, and which thus can be used, over time." The punk style is one example. More generally, a style thus constitutes a "multidimensional selfreferential aesthetic system produced and extended over time" (Aspers 2006, p. 75). In this sense, a style can constitute a lasting cultural reference that can be subjected to fashions but is not a fashion in itself.

Finally, Welters \& Lillethun (2007, p. xxv) explain that a trend is "a direction in which fashion may be heading." A trend encompasses, for example, several fashions and outlines some stylistic aspects, such as color or fabric. The key difference is thus a degree of generality: Fashions are less general than trends.

\section{Where Does Fashion Come From?}

A widespread position in sociology and related disciplines is that fashion became a significant force in society only with the emergence of the bourgeoisie and capitalism in Europe. More specifically, many identify this transition during the European Renaissance in the fourteenth century (Davis 1992, Steele 1998b). Others see it happening later. Braudel (1992, p. 316-17), for example, wrote: "[O]ne cannot really talk of fashion becoming all-powerful before about 1700," even though he also acknowledged that "the really big change came in about 1350."

Is finding an origin of fashion possible, and does it even make sense? For example, Heller (2007) argues that theories about the origin of fashion are biased because there are few sources that can be used to study dress before the medieval period. Similarly, Finnane (2007) explains that the belief that fashion was born in the West is probably related to a lack of interest in, and sources on, other civilizations (such as China) on the part of Western scholars. In fact, fashion is probably as old as dress itself and likely appeared in several civilizations simultaneously. As Steele (1998b) points out, fashion phenomena can be found, for example, in medieval Japan, where telling someone he or she was imamekashi, or "up-to-date," was a great compliment. Likewise, in the first century, the Roman naturalist Pliny the Elder (ca. 77-79 [1952]) described fashion changes in the usage of golden rings but did so without proposing a fully developed theory of fashion.

At the dawn of history, fashionable clothes, which were produced locally, could be afforded only by the upper classes. Gradually, and when groups of people developed better production skills and techniques, ideas, tastes, and fabrics could be diffused through war and conquest or traded, thus increasing the classes that had access to fashionable garments. The relevance of fashion increased with the modernization process of the West, i.e., during the nineteenth century. In the 1920s, Marshall (1923, p. 260) noted, "Until a little while ago it was only the rich who could change their clothing at the capricious order of their dressmakers: but now all classes do it." With the recent growth in prosperity and the increased importance of consumption, mass markets, urbanization, density, and at least some social mobility (Slater 1997), the role of fashion grew even further.

However, a lingering question remains. Do the characteristics of fashion change with its empirical context? Or does fashion present stable features across cultures and historical periods? Craik (1993, p. 4), for example, proposes that we should see fashion as a general phenomenon that is not linked to the historical development of European societies. It appears from our review that although fashion is a type of change that can be found at any historical period or in any culture, its extent and features depend on several factors related to the type of social order at play in the context under consideration. Beyond the important point highlighted above of the existence and extent of a class structure, a crucial structural factor is whether the fashion is deployed in an industrial context or not. This raises the question of the domain of fashion. 


\section{THE DOMAIN OF FASHION}

Fashion as a social phenomenon is not restricted to the domain of clothing and dress. For example, Blumer (1969, p. 275) lists the following fields that fashion affects: "painting, sculpture, music, drama, architecture, dancing, and household decoration." All of these have a clear aesthetic dimension, like fashion, but his list continues with "medicine, ... business management,... mortuary practice,.. literature,.. modern philosophy, ... political doctrines." Even scientific or philosophical truth may be a matter of fashion (see Gadamer 1993, Luhmann 1997).

It is nonetheless hard today to find studies and records of fashions - whether of objects, practices, or representations-that are not related to clothing and dress. There are, however, some notable examples such as the study of the mechanisms that underlie the use and diffusion of children's first names (Besnard \& Desplanques 1986, Lieberson 2000, Lieberson \& Bell 1992). First, as pointed out by Lieberson \& Bell (1992), first names constitute an intriguing case of fashion because, unlike clothing and dress or objects in general, the use and diffusion of first names do not depend primarily on the organized actions of firms, professions, and occupational groups. Similarly, institutional factors such as religious norms or legal constraints, if they sometimes determine the mechanisms defining the choice of names, rather define the pool from which they can be chosen. Zuckerman (2012, p. 225)—who broadly sees fashion as a form of "temporal discontinuity" characterized by a "high degree of concentration in social valuations at a single point in time"-reviews additional cases, including some diffusion studies of managerial practices (Strang \& Macy 2001). He argues that fashion cycles can emerge when "quality differences are relatively minimal" and when no principle anchors valuations in objective reality, giving way to the social construction of value (Zuckerman 2012, p. 239).

Other fields have been explored through a fashion lens; this is the case, for example, for the telecommunications industry (Djelic \& Ainamo 2005), research in management (Abrahamson 1991, 1996), or even science itself (Barnett 1998). These studies, though few in number, support what Blumer (1969) stated about the domain of fashion: that it can potentially expand to any field of human activity; this idea was also put forward and developed by Lipovetsky (1987 [1994]) in his analysis of the spread of what he saw as the "fashion form" to other, nonsartorial fields. Fashion is a central social phenomenon, mechanism, or process that can be applied to any domain. As Braudel (1992, p. 328) wrote, "Fashion... is the way in which each civilization is orientated. It governs ideas as much as costume, the current phrase as much as the coquettish gesture, the manner of receiving at table, the care taken in sealing a letter."

\section{FASHION AS AN INTERDISCIPLINARY TOPIC}

For a long time, fashion as a social phenomenon has had no specific disciplinary home, and only recently have "Fashion Studies" departments emerged, as well as dedicated academic journals such as Fashion Theory, launched in 1997 and edited by Valerie Steele, and Critical Studies in Fashion and Beauty, launched in 2010 and edited by Efrat Tseëlon, Diana Crane, and Susan Kaiser. Because of the current interdisciplinary focus of fashion research, we highlight the main sociologically relevant insights on fashion from other disciplines, their limitations, and the extent to which a sociological approach to fashion can and needs to distinguish itself from developments in other disciplines. Philosophy, economics, geography, and cultural studies are studied in more detail because of the greater amount of work devoted to fashion in these disciplines. We conclude with fashion studies and ask whether there is a distinct sociological voice in this field.

\section{Philosophy}

For centuries, in the Western world, the philosophical debate on fashion-often confounded 
with luxury-was focused almost exclusively on moral questions (Godart 2011), until Adam Smith (1759 [1982], pp. 194-98) switched the attention to the actual philosophical mechanisms of fashion in which he saw the result of an imitation process rooted in what he called "sympathy," a feeling through which individuals relate to others. By imitating the fashions of the rich, Smith argued, individuals participate in their glory and happiness.

Kant, Nietzsche, Gadamer, and Heidegger have also discussed fashion. Philosophers, more generally, have echoed Kant's (1798) dictum that there is no utility to be gained from what is in fashion. For example, Svendsen (2006, p. 157) recently adopted a critical perspective on fashion and concluded that what fashion "can offer does not, despite everything, add all that much to our lives." Kant also mentioned gender, class, and diffusion, themes that Simmel (1904 [1957]) most likely later picked up from him (Gronow 1993).

Nietzsche (1878 [1996], pp. 363-65), moreover, was one of the first to explicitly link fashion to modernity. For him, fashion-which he opposed to the "national costume"-emerged with modernity. The existence of a fashion capital, Paris, was a way to uproot dress from its traditional origins and give way to modernity. Nietzsche, like philosophers in general, was ambivalent vis-à-vis fashion, seeing it as a positive force driving modernity, but also echoing Kant, describing it as "the wheel of taste and vanity" (Nietzsche 1878 [1996], p. 364).

Philosophers have also discussed the applicability of the concept of fashion to social phenomena beyond clothing and dress. When talking about the truth, Gadamer (1990, pp. 4243), following Kant, acknowledges that there is an element of fashion in scientific practice and work (Gadamer 1993, pp. 51, 228). Gadamer suggests that fashion is highly important, but neither he nor Nietzsche can provide us with a definition. Heidegger, who is seen by many as extremely conservative, also could not avoid the notion of fashion. He suggested that what is in fashion is characterized by newness and change, but that additionally it lasts only for a short while (Heidegger 1982, pp. 8-9). Hence, time is a central tenet in the understanding of fashion.

In sum, philosophy is a useful stepping stone for sociologists of fashion because it suggests productive avenues for defining the concept, even though it is often stuck in a "fear of fashion" and a negative moral judgment on this social phenomenon (Hanson 1990).

\section{Economics}

In economics, fashion is often seen as being the opposite of rationality. The "irrationality" of fashion is a widely shared view among economists: Nystrom (1928, p. 68, emphasis in original) wrote that fashion is akin to, "for want of a better name, a philosophy of futility." Veblen (1899) analyzed money and the time spent on fashion-which he lumped together with luxury - as a form of what he called "conspicuous consumption." According to Veblen, fashion, and especially women's fashion, is merely an expression of the wealth of the head of the family of its wearer. But this criticism of fashion is a theme not only developed by classical economists, but also prevalent among more contemporary scholars who imagine conditions under which consumers would be better off "by banning the use of fashion" (Pesendorfer 1995, p. 771).

Economists are not only critical of fashion; some are quite cynical. Marshall (1923, p. 244) wrote, "Rumour says that many a fashion in dress has been planned at a meeting in Paris of representatives of leading dealers and manufacturers." More recently, Becker \& Murphy (2000) have analyzed fashion and fads. They see fashion as a case somewhat different from the standard markets oriented to material and individualistic value. Though the authors clearly make use of some sociological ideas as they expand the rational choice perspective, the analysis is essentially restricted to leaders and followers. There is still a central assumption "that utility does not directly depend on the consumption or status of anyone else" (Becker \& Murphy 2000, p. 107). Other economists have attempted to model fashion (Bikhchandani 
et al. 1992), focusing on diffusion and cascade mechanisms among individuals, shedding some light on how micro-individual decisions lead to macro processes such as fashion.

Although economists, like philosophers, often perceive fashion as being immoral, superficial, or irrational—a view that some sociologists might find unsatisfactory owing to their expectation of value neutrality from social scientists (Weber 1958 [1991])—the modeling of fashion phenomena by economists can be useful to sociologists who are interested in fashion as a diffusion mechanism.

\section{Geography}

In economic geography, the focus is on the global production of fashion, the distribution of knowledge, the features of industrial districts, and the upgrading of the position of low-cost countries in the fashion value or commodity chain (Gereffi 1999). Geographers have, to a lesser extent, analyzed consumption. This field has merged core geographical concepts such as place and concentration with ideas from business economics, such as branding, and ideas from sociology, including networks. The interest geographers have shown in fashion needs to be interpreted in the light of their attention to the spatial concentration of many cultural industries (Power \& Scott 2004).

The notion of fashion brand is relatively new in economic geography (Power \& Hauge 2008), and it is a core product of the interrelation between producers and consumers (Aspers 2010b). The focus has been on the firms that manufacture or retail the clothes (Tokatli 2007, Tokatli et al. 2008), whereas consumption has been somewhat neglected. The uneven development of the value chain is a leading theme: The producers of garments get only a small fraction of the value of the products sold in stores to the final consumers. It is in this light that one should see the relatively large discussion of upgrading within geography. Upgrading is about "enhancing the relative competitive position of a firm" (Schmitz \& Knorringa 2000, p. 181), which often means that a producer-firm gets closer to the final consumer market. There are at least three ways to upgrade: Producers can upgrade their work processes and their products; they can take the knowledge from one sector and make use of it in another (Gereffi 1999, pp. 51-55; Humphrey \& Schmitz 2002, p. 1020); and a firm can functionally upgrade, which involves moving into design and marketing.

Geographers have studied the changing pattern of global garment production chains not only by focusing on areas in which production has grown, but also by looking at the consequences of the increased pressure on producers in Europe and North America who are struggling against the competition from countries with low wages (Evans \& Smith 2006). The geography literature has generated new knowledge on the production of clothes and has tied local consumption to global markets and industrial chains reaching across the globe. This knowledge, which helps shed light on the spatial structure of fashion, can readily be merged with the research produced in sociology and cultural studies, and indeed the disciplines of economic geography and economic sociology have often been fruitfully combined in research (Whitford 2006).

\section{Cultural Studies}

Cultural studies and sociology are historically and intellectually intertwined through a series of common concepts and references, but nowadays they constitute two distinct academic disciplines with their own traditions and institutions. The interest in fashion by cultural studies is multifaceted and in many ways overlaps with that of sociology. Kaiser (2012) gives an overview of the different fields covered by the cultural studies of fashion: nations and the transnational, ethnicity, class, gender, sexuality, and the body.

The cultural studies of fashion arguably started with the work of Hebdige (1979), who developed the concept of "subculture" as applied to youth cultures in the United Kingdom, notably the Punks. At the heart of this approach 
lies the concept of homology, through which all the different aspects of a given subculture are characterized by correspondences. For example, Hebdige explained that the Punks talk like they dress, their opposition to mainstream society being expressed in both domains. This approach has been further developed by, for example, Hodkinson (2002), who has studied the Goth subculture, also in the United Kingdom. Hodkinson's central contribution has been to question the empirical validity of the concepts of subculture and homology that, at least in the Goth context, are looser than what was expected from Hebdige's conceptual apparatus. The concept of a subculture, as related to fashion, has since been expanded to nonWestern settings by, for example Kawamura (2012), who studied Japanese youth subcultures from an ethnographic point of view and showed how Japanese teens have become producers of fashion outside of commercial fashion houses (Kawamura 2006).

Another central theme in the cultural studies of fashion, notably as seen through a feminist lens, is its ambiguity and ambivalence, a theme central in the work of Wilson (2003). Wilson explains that fashion should not be rejected by feminist theory, but rather should be seen as a means of artistic and political expression. Nonetheless, she notes that fashion is inherently ambiguous in the sense that it can also be used for homogenization and oppression. This ambiguity has also been noticed in the use of tattoos, which can be analyzed both as an opposition to the commodification, and as a commodification, of bodies (Fisher 2002).

The question of globalization and the role of fashion in this process are also central in cultural studies. For example, exploring the notion that fashion is an essentially urban phenomenon (Wilson 2003), scholars have asked how cities shape, and are shaped by, fashion; this theme is most notable when examining the emergence of urban centers in the global fashion system (Breward \& Gilbert 2006) beyond the traditional "big four" of Paris, New York, Milan, and London (Breward 2003). Another important topic explored in the context of globalization is whether it leads to a homogenization of dress practices around the world and how "national fabrics" fare in this environment (Paulicelli \& Clark 2009).

Research agendas on fashion in cultural studies and sociology can certainly be merged. We argue that paying attention to structure, in addition to culture (Friedland \& Mohr 2004, Pachucki \& Breiger 2010), is where sociology can add value to cultural studies of fashion, and in this sense fashion is a great site to explore the culture/structure conundrum.

\section{Fashion Studies: Toward an Integrated Paradigm}

As noted by Giusti (2009, p. 9), there has been a recent "explosion" of fashion studies. Fashion studies, or "fashion-ology" (Kawamura 2005), is an interdisciplinary approach to fashion. Several recent books pay heed to Kawamura's intuition and look at fashion from an interdisciplinary angle. In these books, the sociology of fashion, while playing a central role, is mixed with other disciplines. For example, Giusti (2009), synthesizing the developments of several disciplines dealing with fashion, has argued that organizations need to be at the center of a reflection on this topic. In a special themed section on fashion in a 2011 issue of Organization Studies, the role of fashion in management studies is analyzed. The editor, Barbara Czarniawska, writes that "an understanding of fashion may be the key to comprehending many puzzling developments in and among organizations" (Czarniawska 2011, p. 599). This paves the way for adding managerial perspectives to fashion-ology.

There are also concrete suggestions on how a fashion-ological approach could be further developed. For example, starting with the idea that fashion is a "total social fact" at the crossroad of various spheres of social life, Godart (2012) has detailed different regimes and principles of fashion that have emerged historically. Tulloch (2010) has defined the object of fashion studies as "style-fashion-dress," a conceptual system that constitutes a mixed 
research object (Kaiser 2012). Carter (2003) has laid a foundation of fashion studies by identifying its classics, an important task that we also undertake in this article.

Nonetheless, the evolution of fashion research toward interdisciplinarity, which seems to be a major trend, raises the question of the role of sociology in this moving academic context. More precisely, a lingering question that sociologists need to address (Edwards 2011) is whether a specifically sociological point of view on fashion exists. In addition, to what extent should sociologists integrate knowledge from other disciplines into their own research? While we have, at least partially, addressed the second question above, answering the first implies going back to the roots of sociological fashion theory.

\section{THE ROOTS OF SOCIOLOGICAL FASHION THEORY}

The study of fashion in sociology has prestigious roots that are important to understand to better grasp the types of questions that the field is addressing today (Carter 2003; Godart 2011; Kawamura 2005, 2011). Classical sociological research has tied the theoretical analysis of fashion to social structure. The first fully articulated sociological theory of fashion is the "trickle-down theory" or the "class distinction approach" (Davis 1991). Its roots can be traced back to the work of Mandeville (1714 [1924], p. 129, original spelling):

We all look above ourselves, and, as fast as we can, strive to imitate those, that some way or other are superior to us[;] . . the Women of Quality are frighten'd to see Merchants Wives and Daughters dress'd like themselves.... Mantua-makers are sent for, and the contrivance of Fashions becomes all their Study, that they may have always new Modes ready to take up.

Mandeville held a positive view of fashion and luxury in which he saw key drivers of prosperity. Spencer (1897) identified two central processes of fashion: "reverential imitation," i.e., to follow the fashion of the upper class because of its status; and the more challenging "competitive imitation," i.e., to show that there is nothing special about the upper class. Tarde's (1890 [1903]) approach was more neutral, axiologically speaking. He brought in the central aspect of diffusion of fashion in the form of imitation. He distinguished two forms of imitation: customs, which are an imitation of the past and the local; and fashions, which are an imitation of the present and the nonlocal, such as styles and designs created in another country.

The idea of fashion as imitation and distinction was further developed by Veblen (as discussed above) and Simmel, who are usually seen as the two modern fathers of the trickledown theory. Simmel (1904 [1957]) started with an idea of two opposing forces in society: unity (inclusion) and difference (exclusion). Unity essentially entails an idea of belonging, such as to a group, whereas difference refers to the uniqueness that sets an individual apart from others. Simmel argued that the upper class drives the fashion cycle by making sure, when introducing a new style, that people in classes below them are not dressed in the same way. Thus, the upper classes maintain their role by excluding other classes. For each member of a class, however, it is primarily inclusion, not exclusion, that is the main issue, implying that class structure is partly constructed as a result of fashion consumption patterns.

By imitating others, according to Simmel, we decrease our psychological tensions because we can thereby belong to a group or a community. By focusing on the collective level, Simmel rejects the purely psychological explanation of fashion. This is most clearly expressed when he writes that "the [fashion] leader allows himself to be led" (Simmel 1904 [1957], p. 549). However, to dismiss the psychological dimension of fashion is not to omit the existential experience of individuals, each of whom has his or her own unique experience. Simmel's approach set the tone for sociologists, not least because he rejected an object-centered analysis of fashion and focused instead on social dynamics. 
Furthermore, Simmel offered a structural analysis of gender and argued that gender is-at least partially-made through fashion. Finally, Simmel defined important conditions for fashion to exist: People must have the chance to make choices, relatively unfettered from laws; and they must be economically capable to act.

The concentration of people in space, empirically observable in large cities like Berlin, is part of Simmel's explanation of fashion. A further component of his theory is the way he connects fashion to the conditions of his time. Furthermore, Simmel's work is not only a theory of fashion; it is also a theory of society. Simmel's approach implies that fashion is in society and part of its constitution, but it is also something that can be studied as a result of social interactions within societies. This goes beyond the simple causal analysis that sees fashion as a product or a mirror of the evolution of society (Robenstine \& Kelley 1981). The economic historian Sombart (1916) explained that the fast pace at which goods were regarded as obsolete and were replaced was caused by mobility, by the concentration of people in cities, by the preference for change, and above all, by the pressure to change. Sombart did not present a theory of fashion but did list characteristic traits of what he nonetheless called a theory of fashion. The first is the increased number of objects that are drawn into the logic of fashion; the second is the general extension of fashion; and the third is the increased pace of fashion. Sombart looked both at the production side, for example the design of garments, and the consumption side when trying to understand fashion. In fact, in contrast to Simmel and Veblen, Sombart stressed the role of the producing companies for the creation and maintenance of fashion. In doing so, he also spoke about socialization of consumers as key elements in modern capitalism.

The trickle-down theory, which constitutes the "standard theory of fashion" (Godart 2011), was challenged by Blumer (1969), who developed his own "collective selection" theory in which the movements of fashion come first, followed by the distinction and imitation gamings of social classes. In his view, designers and other tastemakers play a key role by translating tastes into designs. This perspective opened the way to multiple challenges to the trickle-down approach, and empirical studies demonstrated other movements such as trickle-across or trickle-up that saw the evolution of fashions as being across social classes or from the bottom up (Crane 1999, McCracken 1989). Similarly, Vinken (2005, p. 4) saw fashion as inherently "performative," as a source of negotiated societal change rather than as a mirror of social structure. The collective selection approach has also been used to understand, for example, commercials (Solomon \& Greenberg 1993) and to constitute a full-fledged "symbolic interactionism" theory of fashion (Kaiser et al. 1995). Finally, Davis (1991, 1992) used the collective selection approach as a starting point for his own sociological approach based on the ambivalence of fashion and advocated for the need to look at the industry to understand the underlying mechanisms of fashion.

\section{FROM DIFFUSION TO PRODUCTION}

\section{The Production of Fashion}

Despite the potentially unlimited domain of fashion, sociologists have largely studied the apparel industry when exploring fashion. On the basis of these studies, one can outline several themes that have captured their interest. We begin by discussing the production of fashion. Essentially, this literature unveils what is happening before the act of purchase by final customers in stores or online. Although fashion, strictly speaking, comes into being only when consumers make choices, their choices are framed by what is offered. We must remember that, although the existence of a market is not a necessary condition for the existence of fashion (Lieberson 2000), any domain in which we find fashion can be seen as an opportunity for profit making in 
capitalist societies. We are not suggesting that production is more relevant than consumption, but we do argue that to understand fashion, we must combine consumption and production, as advocated, for example, by McRobbie (1997).

The study of fashion diffusion has focused on two main topics: the understanding of the overall process and the identification of fashion leaders. The fashion process has been theorized in various ways, notably as a "product life cycle" (Sproles 1981), but the nature of fashion is such that some styles can come back over time (Cappetta et al. 2006). Moreover, fashion leaders have been defined as "the first members of their social group to learn about and wear a new fashion when it appears in the market" (Goldsmith et al. 1996, p. 242). They make the success or failure of styles (Polegato \& Wall 1980) and thus are the ones who drive the fashion cycles.

Barber \& Lobel (1952) lamented the broad use of the concept of fashion and suggested a focus on "the American class structure, age-sex roles, and economic system," three interrelated dimensions. They pointed out that what made the American fashion industry specific was the existence of mass production, whereas France was still emphasizing haute couture, i.e., highquality custom-made garments, mostly for women. They opened the way for comparative studies of the fashion industry. Blumer (1969) focused on the producers themselves. Although his perspective is a general statement about fashion, it is also an attempt to look at the creative process as one of gradual decisions of several actors, acknowledging the tension between art and commerce that exists at the heart of fashion. Bourdieu (1984b) offered a detailed description of Parisian haute couture by studying the structure of this field. Specifically, he looked at the polarization between conservative and innovative fashion houses and the ensuing field dynamics. Fashion is a window on the economy and capitalism: "Fashion is the favored child of capitalism. It stems from the latter inner characteristics and expresses its uniqueness unlike any other phenomenon of our social life in our time" (Sombart 2001, p. 225).

\section{The Fashion Industry's Structure}

As suggested by Aspers (2001, 2010a) and Godart (2012), the fashion industry, like any other industry, can be described using the model developed by White (2002), in particular the idea that a market is constituted by multiple networks that connect an upstream of suppliers to a downstream of customers through a market interface made of producers. The fashion industry can thus be considered an interface that links a set of suppliers, for example textile makers, to customers all over the world. In this instance, producers may be luxury fashion houses such as Chanel, ready-to-wear firms like Hugo Boss, or mass-market chain store producers such as H\&M. These producers are organizations (Giusti 2009) in which creative teams draw their inspiration from several sourcesfor example, art (Hollander 1993)—-to design items that will please customers. The study of the organizations and their fate can then be conducted from a "production of culture" (Crane 1997) or a "genealogical" (Wenting 2008) point of view.

Although fashion, especially the production of garments, is a global affair, national fashion industries still prevail, each with their specific features. Djelic \& Ainamo (1999) have explored some of these features, distinguishing the French model organized around umbrella conglomerates such as LVMH and PPR, the Italian model based on local economic clusters, and the American model based on licensing. Cities also have specific identities that are attached to the designs produced within their confines, such as in the case of Milan, which represents a cachet of quality and excellence in ready-to-wear (Segre Reinach 2006).

The fashion industry, like all creative industries (Caves 2000), is characterized by a high level of uncertainty (e.g., Bielby \& Bielby 1994, Godart \& Mears 2009). Thus, several institutions (Kawamura 2005) mitigate the uncertainty in this industry-the "fog of fashion" (White et al. 2007, p. 194)— and facilitate the production process, such as fashion magazines (Moeran 2006) or fashion 
museums (Steele 1998a) that help diffuse fashion knowledge to the population; fashion schools that create a common understanding of what fashion is, for example, in an urban setting (Rantisi 2002a,b); fashion fairs that constitute "temporary clusters" (Bathelt \& Schuldt 2008) and help the exchange and diffusion of fashion ideas; or forecasting bureaus that diffuse industry-specific knowledge about trends and styles to producers (Godart 2012, p. 70). Additionally, the fashion industry is ordered around several professions such as fashion designers-who are often organized in national professional associations, such as the Council of Fashion Designers of America in the United States and the Chambre Syndicale de la Haute Couture in France (Kawamura 2004) - or fashion photographers (Aspers 2001), as well as occupations such as fashion models (Godart \& Mears 2009, Mears 2011). Fashion designers have been the objects of specific research. For example, Volonté (2008) explored the social role of fashion designers, noting that the fashion process would not exist without professions to bring it to life.

\section{Manufacturing}

The garment sector was one of the first to be industrialized in the eighteenth century (Farnie \& Jeremy 2004). It is also one of the first to have become global, initially with the supply of raw material and later with full-package solutions. However, as pointed out by Dunlop \& Weil (1996), large segments of the apparel industry are still characterized by the wide use of the "Progressive Bundle System" (PBS) established in the 1930s, in which each day is devoted to a single operation, whatever its length, leading to a slow production process. New, modular techniques have emerged, however, that accelerate production and sustain the rise of fast fashion that supplies customers with ever-changing designs at low cost (Doeringer \& Crean 2006).

The production of fashion is often completed in close collaboration with the buyers, and one strategy that is often employed to bridge the uncertainty of the market is the formation of long-lasting ties between producers and their supplies (Aspers 2010a, Uzzi 1996). The buying and selling of clothes are conducted not only in the consumer market, but also in fairs (Skov 2006). In some cases, garments are traded via several steps before consumers can purchase them, and these intermediary traders have influence on what is available in retail (Entwistle 2009). Strictly speaking, garments are the output of the production process; these become fashion items if and only if they are accepted first by fashion editors and other gatekeepers and, above all, the final customers (Aspers 2010a).

\section{The Fashion Industry's Environment}

Fashions do not evolve in a social vacuum, and their evolution and diffusion are constrained by legal frameworks. First, sumptuary laws (Hunt 1996) — which were abolished for the most part in the West but still exist elsewhere-constrain the consumer regarding clothing (such as the colors that can be worn and by whom), food, and the like. However, the relationship of fashion to regulations goes beyond the existence of formal and legal norms about what people can wear (keeping in mind that informal norms always exist). Fashion, as an industry and change process, can be constrained by law as to what can be designed and produced. The debate regarding intellectual property in fashion has been polarized between two positions. According to the first position, fashion is essentially a status-based industry. What matters are not the designs but the labels and logos, and they need to be legally protected (Raustiala \& Sprigman 2006). The second position is that fashion needs intellectual property law to protect innovation. In this perspective, a certain level of imitation ("remixing," which consists of combining designs) could be authorized (Hemphill \& Suk 2009). This legal debate addresses the question of the nature of fashion: Is it located in the objects themselves, and thus capable of being owned, such as, for example, through intellectual property rights, or is it a purely social mechanism that is the result of 
interaction between actors? This debate around intellectual property in fashion also sheds light on the core mechanisms at play and on the necessity of imitation for fashion to exist.

Another set of constraints that weigh on fashions are moral norms. They explicitly make the link between the production and consumption sides because they often originate from clients and modify practices among producers. The main research topic here is ethical fashion. Fashion, as an industry, has often been criticized because of poor working conditions, particularly in low-cost countries, and because of its impact on the environment. Research has shown that despite these concerns, consumers are not necessarily ready to pay a premium price for ethical fashion-that is, clothing that is produced under sustainable social and environmental norms (Joergens 2006)—unless they trust the brands that produce ethical fashion and have a good knowledge of their practices (Shen et al. 2012).

\section{THE CONSUMPTION OF FASHION}

\section{Why Consumption Matters}

First and foremost, consumption refers to the purchase of services and goods, such as clothes, but more importantly, it also refers to the use of such services and goods and to a way of life in general. Consumption is largely relational (Aspers \& Beckert 2011), given that the act of purchase relates an individual to what others think and do. Hence, individuals are not born with an innate interest in fashion and a propensity to make social distinctions, but they are born into a society in which fashion and social distinctions are taken for granted and valued. It is through usage that fashion comes into being, for example when firms use a certain form of advertising directed at customers or when people exhibit and display their bodies in certain ways. We repeat, however, that fashion is not necessarily connected to a market context, in which producers offer alternatives from which consumers can choose.
Today, we must take into account the increased importance of consumption facilitated by the Internet (Kawamura 2006). Indeed, in many Western economies, fashion is characterized by its reflexive character, shown in the way the environment affects and is affected by fashion. In addition, we can increasingly see this trend occurring in large emerging economies such as India, Brazil, Turkey, or China. Furthermore, fashion represents the clearest sign of a general "aestheticization" of social life (Postrel 2004)—both material, including most consumer objects and the appearance of the body, and immaterial, including ways to talk and express oneself. In line with this trend, some sociologists have studied the role of fashion as an economically important phenomenon, using terms such as "aesthetic markets" (Aspers 2001) and "aesthetic economy" (Entwistle 2009).

\section{The Meaning of Clothes}

Several approaches try to account for the meaning people attribute to clothes and adornment in modern societies, notably through the act of consumption. The semiotics of fashion, for example, by Barthes (2006) assumes that there is a "lexicon and syntax" in clothing that resemble the structure of a language. Barthes is also clear in his approach; he does not focus on what he sees as sociological factors, such as, for example, manufacturing, but on fashion texts that are extracted from fashion magazines.

Extending the semiotic approach to fashion, some have seen fashion and clothing as a form of communication (Barnard 1996, Bohn 2000). A central semiotic idea is that the signifier, which may be a word or a garment, is given meaning by the signified. Thus, a signifier does not stand by itself, and only those who know the "code"-that is, "a set of shared rules" similar to a language — can understand the meaning of the garment (Barnard 1996, pp. 78-79). An object, according to Barnard, both denotes and connotes. Denotation refers to the garment's characteristics, such as its color or fabric. Connotation refers to the meaning of the garment in terms of, for example, its regular users. As 
pointed out by Aspers (2010a, p. 197), the semiotic approach cuts off what most sociologists consider the most central dimension of meaning, namely how actors produce, interpret, and use fashion. Researchers that attempt to uncover the "hidden meaning" of garments (van Leeuwen \& Jewitt 2001) often forget that the clothes by themselves, out of their social context, have no meaning. They acquire meaning because they are embedded in social relations and contexts. In this sense, clothing is, at best, a code characterized by "undercoding" (Davis 1992, p. 11).

\section{Body, Gender, and Ethnicity}

The relationship between fashion and the body is central. As Entwistle (2000, p. 1) pointed out, "Fashion is about bodies: it is produced, promoted and worn by bodies" and, as Benjamin (1999, p. 79) wrote, "Every fashion couples the living body to the inorganic world." Tattoos, for example, adorn and modify bodies. They are partially driven by fashion mechanisms and are sometimes used to express "antifashion" positions (Sweetman 1999). Fashion models' bodies are reified to fit industrial constraints (Czerniawski 2012, Entwistle 2002, Mears \& Finlay 2005); clothes are used to classify bodies, as well as to define and sustain gender differences, such as the use of pink and blue for girls and boys, respectively, in the West since the 1920s (Paoletti 1987).

Gender differences have a major impact on fashion, and in turn, fashion is a forceful purveyor of cultural norms and symbols that can shape and express gender differences. The feminine and masculine sides of the fashion industry are clearly delimited, with different creative and productive processes, such as different fashion shows. Today, the feminine side clearly prevails (Manlow 2007). Historically, this has not always been the case. For example, in eighteenth-century Europe, men's fashion was at least as extravagant and significant as women's fashion. In Europe, the nineteenth century saw the emergence of a sober and simpler dress for men. This is because, as first theorized by Goblot (1925 [2010]), in European bourgeois families men had to show their focus on work through understated clothes but simultaneously had to display their wealth through the adornment of their wives. Today, gender boundaries are not as clearly defined, even though they are still prevalent all over the world. The more recent feminist approach to fashion has led to a deconstruction of binary gender oppositions (Kaiser 2012), paying heed to Wilson's (2003) call not to dismiss fashion.

Ethnicity has been shown to influence fashion (and to be influenced by it) in several contexts, including the role of designers from Japan in French fashion (Kawamura 2004). Another example is Lieberson \& Bell's (1992) focus-in the case of the United States-on gender, ethnicity, and class differences to explain the choice of first names. For example, their research shows that among Caucasian Americans, girls' first names tend to change more often than boys' names and to be more novel. They explain that this pattern fits with the wider belief that women need to be attractive through their first name, whereas men's names are supposed to embody social stability. They conclude their study by stating that "[e]ven in situations where organizations and institutions seek to alter and manipulate tastes and fashions, as through advertising, it is likely that there are a set of underlying societal and cultural dispositions that set limitations and boundaries around such efforts" (Lieberson \& Bell 1992, p. 549). More generally, Eicher (1999) argues that ethnicity and dress have to deal with space and time, in the sense that ethnic dress varies not only with the location of its wearers (Hansen 2004) but also with the period under consideration and is in no way stable. In this sense, ethnic dress is not akin to tradition. It belongs to fashion and is a major driver of identity.

\section{Class and Identity}

Over time, consumption of fashion has moved from being class-oriented to lifestyle-oriented (Crane 2000, pp. 134-36). Class fashion was characterized by a centralized system of 
production, whose output was followed by buyers. Codes of dress and behavior meant that variation of clothes and styles was limited. A more diversified society goes hand in hand with a more diversified set of fashions. Today, we have not only more fashion industry segments than in the past but also more fashions competing with one another, and there are many more fashion capitals, consumer groups, etc. Fashion is far more diversified and also individualized. This diversity, however, has not erased important questions related to consumption and the political tensions that go with it (Enstad 1998): Who is in and who is out? Research on fashion often assumes that anyone can have access to the desired products, but in many instances, this is not the case, and research on fashion ought to take this fact seriously (McRobbie 1997).

Furthermore, issues of class and inequality can today be analyzed not only using occupations, professions, and positions in the labor market, but also using consumption patterns and lifestyle-based identities, as Bourdieu (1984a) suggested. Class-based and identity fashions are not incompatible. For example, in his study of the nineteenth-century French bourgeoisie, Goblot (1925 [2010]) explained that this social class was characterized by a double mechanism that guaranteed the bourgeoisie's existence, development, and overall identity. First, there was the barrier mechanism through which this class made sure it could control access to its ranks, and then the leveling mechanism that ensured that its members were more or less equal in order to reduce internal conflicts. Fashion was a key factor in the definition of the bourgeois identity in nineteenth-century France because, via the trickle-down mechanism, the French bourgeoisie was able to exclude other classes while fostering its own identity.

However, it is also true in other contexts. For example, most societies use clothing to define class- and occupation-based identities. Social groups such as subcultures have been identified as being a highly relevant site for the exploration of fashion and its relationship to lifestyles and identity (Hebdige 1979, Hod- kinson 2002). Nevertheless, the expression of identity through fashion remains ambivalent, mostly because interpreting fashion is loaded with uncertainty (Davis 1992). From a social psychological point of view (Kaiser 1997), identity formation in relation to fashion needs to be understood in context. In this vein, Péretz (1992) argued that the "vestimentary identity" of fashion buyers is partially constructed through their interactions with salespersons in the concrete setting of fashion retail. More recently, the focus has been on cognitive factors. Adam \& Galinsky (2012), for example, looked at the effects of specific clothing (lab coats) on wearers. Under experimental conditions, they found that wearing lab coats increased the "attentiveness" and "carefulness" of individuals because of the identity change induced by the clothes they wore.

\section{DISCUSSION: TOWARD A THEORY OF FASHION}

We began this review by defining fashion negatively in relation to a set of key selected concepts—fad, innovation, style, and trend. We also analyzed its etymology. It follows from this discussion that fashion is a social phenomenon that may apply to almost any human activity. Drawing on the existing research by sociologists, as well as by others who have researched this topic, it is possible to advance the discussion by presenting the scientific stepping stone that hitherto has been missing: a definition of fashion. We propose to define fashion as an unplanned process of recurrent change against a backdrop of order in the public realm.

A condition of the existence of fashion is the possibility for free agents to act. Fashion is essentially a social process of mutual adaptation. In this process, actors are free to decide if and to what extent they will adopt a new object, practice, or representation. However, actors can be influenced not only by their peers' preferences but also by third parties' strategies and institutional power. Fashion, in other words, can be influenced, but it cannot be planned or imposed. As Corona \& Godart (2010, p. 286)
Fashion: an unplanned process of recurrent change against a backdrop of order in the public realm 
wrote, following Molotch (2003) and Benjamin (1999), there is "no bootcamp" for fashion. The contradictions and difficulties related to planned fashion have been shown in studies of central agencies that tried to organize fashion in the Soviet Union (Gronow 2003, Gurova 2009). Fashion emerges from a process of mutual adaptation and thus links micro decisions to macro processes, but numerous attempts to organize and tame it are made to reduce its inherent uncertainty, such as when producers try to persuade people to use, and often buy, what they offer, especially through advertising (Luhmann 2000, pp. 47-48), or when they organize the production process via professional association, fairs, or forecasting bureaus. Fashion ceases when change is not driven by actors' wants and unrestricted choices. In other words, fashion is likely to appear only in societies in which distinctions are accepted and even desired, not in which similarity is a central guiding principle.

Moreover, fashion is a process and, as such, is extended in time. In this process, something new is introduced that replaces or complements something that already existed (Belleau 1987). Fashion need not be cumulative, although it can be (Godart 2012, p. 5). Adorno (2002, p. 463) explains this, referring to popular music: "Any rhythmical formula which is outdated, no matter how 'hot' it is in itself, is regarded as ridiculous and therefore either flatly rejected or enjoyed with the smug feeling that the fashions now familiar to the listener are superior." Ferguson (2006) observed similar mechanisms in French cuisine. That this process of change and replacement of an object, practice, or representation by another has no predetermined beginning or end makes it recurrent. It is ongoing and can, but must not, be characterized by cyclical elements. Hence, cyclicality, in which older elements regularly reappear (Vinken 2005), is not necessary for fashion to exist, and innovations can become the object of fashion. In fact, what is recurring is change itself, not the elements that change. In this sense, we see cyclicality as a specific case of recurring change. The logic of this process through which something comes in and out of fashion is the core of the theory. Obviously, not all objects, practices, or representations that are considered new in a given context will catch on and be adopted or mimicked by others. It is a selection process that takes place in which only some of the objects, practices, or representations that are considered new are taken up by others, and only these can become fashionable.

It follows that fashion is inherently relational. For something to be in fashion it must be adopted by a large number of actors. Only when a growing number of people or organizations start doing what only a few are already doing can we talk about fashion. But once a phenomenon is too common or too widespread and "everyone" has adopted it, it falls out of fashion. Social structure and status matter when we analyze the diffusion process through which we can understand the undulations of fashion. Some celebrities, role models, icons, popular peer group members, or high-status organizations are more likely to be imitated by others and thus can become fashion leaders (Aspers 2010a, pp. 43-44). Being a fashion leader may be a central element of a personal identity. But fashion may be equally important to those who follow it, those who try to be antifashion, and those who strive to be out of fashion. All these groups further the fashion process because each attitude toward fashion, whatever it is, reaffirms its centrality. Notably, the process need not be fully conscious.

Fashion is simultaneously inclusive and exclusive. Some actors may want to create differences, i.e., act to divert from what is existing or too common. This is best interpreted as an act of individuality. Others aim to make sure that they, too, are on the bandwagon, which is to say that fashion may also be seen as an act of collectivity, as Nietzsche (1878 [1996], pp. 363-65) observed. Besides, actors have different thresholds for the adoption process (Watts \& Dodds 2007) so that some are early adopters, others jump on the bandwagon later, and still others decide to stay out of the process altogether.

Furthermore, fashion is public, and some form of space is needed for its diffusion. For 
fashion to exist, the object, practice, or representation in question must be observable by most or by all, for example on the Internet or in a mall. It must also be financially accessible to actors. Various theories of diffusion and adaptation can be used to explain how this occurs (Rogers 1983), but it is not necessary to specify all their details here, such as diffusion through observations in public or via information that is communicated in networks.

Finally, our definition includes the notion of order. Change in fashion takes place against a backdrop of order; not everything can change at the same time, and fashion is somewhat constrained by what it replaces (Belleau 1987). Consequently, there can be no fashion in a situation of chaos or lack of structure. In these situations, there can be only fads. Fashion, however, can take place only given a background that is more stable than what is about to change. But how is it possible to speak of both fashion in management styles, which may change only every other decade, and fashion in lipstick colors, shoe styles, or drinks, which change so often?

To do this we must see both order and change in relation to time. Something can be in flux only if there is a relatively more stable background of order than what is changing. In other words, though nothing is inherently stable, some of the social constructions, like styles, institutions, habits, and so on, are more stable than others, and as such they may provide the background that makes people perceive certain fashion changes. In sum, the phenomenological perceptions of order and change are the conditions of how long a fashion is to exist and of whether we shall speak of fashion at all.

\section{CONCLUSION: WHAT CAN BE DONE?}

We have reviewed the existing literature on fashion, including several disciplines related to sociology. The studies reviewed in this article, especially the more recent ones, have put fashion on the sociological map. We have seen that the central aspects of fashion-diffusion, imita- tion, and distinction - have been noted by most researchers. What direction should the sociology of fashion take now? There are two main tasks that we have identified.

We have seen that although many scholars say that fashion is not necessarily restricted to apparel, most studies have focused on clothing and dress. Like Edwards (2011), we suggest that a sociological understanding of fashion needs to go beyond dress, even though it is a privileged setting for the exploration of fashion given its inherent features. Studying other empirical domains should be the focus of sociologists if they want to develop a more comprehensive understanding of fashion as a social phenomenon and to develop a sociological voice among all the disciplines that look at fashion. Furthermore, most studies focus on one field only. We have not seen comparative studies of fashion. It would be intriguing to study not only fashions of the same idea, object, or representation in different contexts (e.g., industries, countries, or epochs), but also fashions of different objects, practices, or representations in the same context. Such a perspective would allow a better understanding of social processes at play in the definition of identities, and in the development of practices and representations.

The other main task is to further develop theory. That would allow us to systematize existing knowledge and to develop additional research. We have taken a few steps in this direction, but much more can be done. For example, if we look at the current field, production and consumption could be further combined. This would allow a better understanding of the institutional, organizational, structural, or cultural conditions under which fashion as change is deployed. Fashion shapes its surrounding social environment and is simultaneously shaped by it. A focus on class, gender, ethnicity, nationsto cite a few topics-can only help clarify the fashion process, as long as its inherent features as a type of change are not lost from sight.

However, before further theoretical developments can be made, conceptual work is necessary. The concept of fashion has not been fully clarified. As we have explained, it is a way 
of doing and making things that is bounded in space and time and involves collectives. In this sense, it is a type of change, like fads or innovations. Exploring how these different types of change are intertwined would be a valuable exercise and would shed further light on the important sociological issue of the diffusion of practices and representations.

Fashion is a key social process that can help us understand social relations in general (Erner
2006), from imitation and distinction mechanisms to identity formation, ethnicity, gender, and production and consumption. It is also closely related to canonical sociological questions such as being and order and the culture/structure conundrum. Developing research on this topic and phenomenon would facilitate the understanding of the antecedents and consequences of order and change in general.

\section{DISCLOSURE STATEMENT}

The authors are not aware of any affiliations, memberships, funding, or financial holdings that might be perceived as affecting the objectivity of this review.

\section{ACKNOWLEDGMENTS}

P.A. gratefully acknowledges the support from ERC (CEV263699) and VR (2009-1958). The authors thank Diana Crane, Priscilla Ferguson, Susan Kaiser, Thierry Maillet, Alain Quemin, Katinka Quintelier, Sorah Seong, and Nebahat Tokatli for providing feedback, suggestions, or intellectual support for this article. We are also indebted to Karen Cook and an anonymous reviewer for their thoughtful reads.

\section{LITERATURE CITED}

Abrahamson E. 1991. Managerial fads and fashions: the diffusion and rejection of innovations. Acad. Manag. Rev. 16:586-612

Abrahamson E. 1996. Management fashion. Acad. Manag. Rev. 21:254-85

Adam H, Galinsky AD. 2012. Enclothed cognition. F. Exp. Soc. Psychol. 48:918-25

Adorno T. 2002. On popular music. In Essays on Music, ed. T Adorno, pp. 437-70. Berkeley: Univ. Calif. Press Aspers P. 2001. A market in vogue, fashion photography in Sweden. Eur. Soc. 3:1-22

Aspers P. 2006. Markets in Fashion: A Phenomenological Approach. London: Routledge

Aspers P. 2010a. Orderly Fashion: A Sociology of Markets. Princeton, NJ: Princeton Univ. Press

Aspers P. 2010b. Using design for upgrading in the fashion industry. F. Econ. Geogr. 10:189-207

Aspers P, Beckert J. 2011. Introduction-value in markets. In The Worth of Goods: Valuation and Pricing in the Economy, ed. J Beckert, P Aspers, pp. 3-41. New York: Oxford Univ. Press

Barber B, Lobel LS. 1952. "Fashion" in women's clothes and the American social system. Soc. Forces 31:124-31

Barnard M. 1996. Fashion as Communication. London: Routledge

Barnett C. 1998. The cultural turn: fashion or progress in human geography? Antipode 30:379-94

Barthes R. 2006. The Language of Fashion. Oxford/New York: Berg. 183 pp.

Bathelt H, Schuldt N. 2008. Between luminaires and meat grinders: international trade fairs as temporary clusters. Reg. Stud. 42:853-68

Becker GS, Murphy KM. 2000. Social Economics: Market Behavior in a Social Environment. Cambridge, MA: Belknap Press Harvard Univ. 170 pp.

Bell Q. 1976. On Human Finery. London: Hogarth

Belleau BD. 1987. Cyclical fashion movement: women's day dresses: 1860-1980. Cloth. Text. Res. F. 5:15-20

Benjamin W. 1999. The Arcades Project. Cambridge, MA: Harvard Univ. Press

Besnard P, Desplanques G. 1986. Un Prénom pour toujours: la cote des prénoms, hier, aujourd'hui et demain. Paris: Balland 
Bielby WT, Bielby DD. 1994. All hits are flukes: institutionalized decision making and the rhetoric of network prime-time program development. Am. F. Sociol. 99:1287-313

Bikhchandani S, Hirshleifer D, Welch I. 1992. A theory of fads, fashion, custom, and cultural change as informational cascades. F. Polit. Econ. 100:992-1026

Blumer H. 1969. Fashion: from class differentiation to collective selection. Sociol. Q. 10:275-91

Bohn C. 2000. Kleidung als Kommunikationsmedium. Soz. Syst. 6:111-35

Bourdieu P. 1984a. Distinction: A Social Critique of the fudgement of Taste. Cambridge, MA: Harvard Univ. Press

Bourdieu P. 1984b. Questions de Sociologie. Paris: Les Ed. Minuit

Braudel F. 1992. Civilization and Capitalism, 15th-18th Century. Vol. I: The Structure of Everyday Life. Berkeley: Univ. Calif. Press

Breward C. 2003. Fashion. Oxford, UK: Oxford Univ. Press

Breward C, Evans C, eds. 2005. Fashion and Modernity. Oxford, UK: Berg

Breward C, Gilbert D, eds. 2006. Fashion's World Cities. Oxford, UK: Berg

Cappetta R, Cillo P, Ponti A. 2006. Convergent designs in fine fashion: an evolutionary model for stylistic innovation. Res. Policy 35:1273-90

Carter M. 2003. Fashion Classics from Carlyle to Barthes. Oxford, UK: Berg

Caves RE. 2000. Creative Industries: Contracts Between Art and Commerce. Cambridge, MA/London: Harvard Univ. Press. 454 pp.

Corona V, Godart F. 2010. Network-domains in combat and fashion organizations. Organization 17:283-304

Craik J. 1993. The Face of Fashion: Cultural Studies of Fashion. London: Routledge

Crane D. 1997. Globalization, organizational size, and innovation in the French luxury fashion industry: production of culture theory revisited. Poetics 24:393-414

Crane D. 1999. Diffusion models and fashion: a reassessment. Ann. Am. Acad. Polit. Soc. Sci. 566:13-24

Crane D. 2000. Fashion and Its Social Agendas: Class, Gender, and Identity in Clotbing. Chicago: Chicago Univ. Press

Crane D, Bovone L. 2006. Approaches to material culture: the sociology of fashion and clothing. Poetics 34:319-33

Czarniawska B. 2011. Introduction to the special themed section: fashion in research and in management. Organ. Stud. 32:599-602

Czerniawski AM. 2012. Disciplining corpulence: the case of plus-size fashion models. 7. Contemp. Ethnogr. 41:127-53

Davis F. 1991. Herbert Blumer and the study of fashion: a reminiscence and a critique. Symb. Interact. 14:1-21

Davis F. 1992. Fashion, Culture, and Identity. Chicago: Univ. Chicago Press

Djelic M-L, Ainamo A. 1999. The coevolution of new organizational forms in the fashion industry: a historical and comparative study of France, Italy, and the United States. Organ. Sci. 10:622-37

Djelic M-L, Ainamo A. 2005. The telecom industry as cultural industry? The transposition of fashion logics into the field of mobile telephony. In Research in the Sociology of Organization, ed. C Jones, PH Thornton, 23:45-80. Bingley, UK: Emerald

Doeringer PB, Crean S. 2006. Can fast fashion save the US apparel industry? Soc. Econ. Rev. 4:353-77

Dunlop JT, Weil D. 1996. Diffusion and performance of modular production in the U.S. apparel industry. Ind. Relat. 35:334-55

Edwards T. 2011. Fashion in Focus: Concepts, Practices and Politics. London: Routledge

Eicher JB. 1999. Introduction: dress as expression of ethnic identity. In Dress and Ethnicity: Change Across Space and Time, ed. JB Eicher, pp. 1-6. Oxford, UK: Berg

Enstad N. 1998. Fashioning political identities: cultural studies and the historical construction of political subjects. Am. Q. 50:745-82

Entwistle J. 2000. The Fashioned Body. Fashion, Dress and Modern Social Theory. Cambridge, UK: Polity

Entwistle J. 2002. The aesthetic economy: the production of value in the field of fashion modeling. F. Consum. Cult. 2:317-40

Entwistle J. 2009. The Aesthetic Economy of Fashion: Markets and Value in Clothing and Modelling. Oxford, UK: Berg 
Erner G. 2006. Victimes de la mode? Comment on la crée, pourquoi on la suit. Paris: La Découverte

Evans Y, Smith A. 2006. Surviving at the margins? Deindustrialisation, the creative industries, and upgrading in London's garment sector. Environ. Plan. A 38:2253-69

Farnie D, Jeremy D, eds. 2004. The Fibre That Changed the World. New York: Oxford Univ. Press

Ferguson P. 2006. Accounting for Taste: The Triumph of French Cuisine. Chicago: Univ. Chicago Press

Finnane A. 2007. Changing Clothes in China: Fashion, History, Nation. New York: Columbia Univ. Press

Fisher JA. 2002. Tattooing the body, marking culture. Body Soc. 8:91-107

Friedland R, Mohr J. 2004. The cultural turn in American sociology. In Matters of Culture: Cultural Sociology in Practice, ed. R Friedland, J Mohr, pp. 1-70. New York: Cambridge Univ. Press

Gadamer H-G. 1990. Wabrheit und Methode, Grundzüge einer philosophischen Hermeneutik, Band 1, Hermeneutik. Tübingen: Mohr

Gadamer H-G. 1993. Wabrheit und Methode, Ergänzungen, Register. Band 2, Hermeneutik II. Tübingen: Mohr

Gereffi G. 1999. International trade and industrial upgrading in the apparel commodity chain. 7. Int. Econ. 48:37-70

Giusti N. 2009. Introduzione allo studio della moda. Bologne: Il Mulino

Goblot E. 1925 (2010). La Barrière et le niveau. Paris: PUF

Godart F. 2011. Penser la mode. Paris: IFM/Regard

Godart F. 2012. Unveiling Fashion: Business, Culture, and Identity in the Most Glamorous Industry. Basingstoke, UK/New York: Palgrave Macmillan

Godart F, Mears A. 2009. How do cultural producers make creative decisions? Lessons from the catwalk. Soc. Forces 88:671-92

Goldsmith RE, Reinecke Flynn L, Moore MA. 1996. The self-concept of fashion leaders. Cloth. Text. Res. F. $14: 242-48$

Gregory P. 1947. An economic interpretation of women's fashion. South. Econ. 7. 14:148-62

Gronow J. 1993. Taste and fashion: the social function of fashion and style. Acta Sociol. 36:89-100

Gronow J. 2003. Caviar with Champagne: Common Luxury and the Ideals of the Good Life in Stalin's Russia. Oxford, UK: Berg

Gronow J. 2009. Fads, fashions and 'real' innovations: novelties and social change. In Time, Consumption and Everyday Life, ed. E Shove, F Trentmann, R Wilk, pp. 129-42. Oxford, UK: Berg

Gurova O. 2009. The art of dressing: body, gender, and discourse on fashion in Soviet Russia in the 1950s and 1960s. See Paulicelli \& Clark 2009, pp. 73-92

Hansen KT. 2004. The world in dress: anthropological perspectives on clothing, fashion, and culture. Annu. Rev. Anthropol. 33:369-92

Hanson K. 1990. Dressing down dressing up — the philosophic fear of fashion. Hypatia 5:107-21

Hebdige D. 1979. Subculture: The Meaning of Style. London: Routledge. 195 pp.

Heidegger M. 1982. Hölderlins Hymne “Andenken”, Gesamtausgabe, II Abt.: Verlesungen 1923-1944 Bd. 52. Frankfurt am Main: Klostermann

Heller S-G. 2007. Fashion in Medieval France. Cambridge, UK: DS Brewer. 206 pp.

Hemphill CS, Suk J. 2009. The law, culture, and economics of fashion. Stanford Law Rev. 61:1147-99

Hodkinson P. 2002. Goth: Identity, Style and Subculture. Oxford, UK: Berg

Hollander A. 1993. Seeing Through Clothes. Berkeley: Univ. Calif. Press

Humphrey J, Schmitz H. 2002. How does insertion in global value chains affect upgrading in industrial clusters? Reg. Stud. 36:1017-27

Hunt A. 1996. Governance of the Consuming Passions: A History of Sumptuary Law. New York: St. Martin's

Joergens C. 2006. Ethical fashion: myth or future trend? F. Fash. Mark. Manag. 10:360-71

Kaiser SB. 1997. The Social Psychology of Clotbing: Symbolic Appearances in Context. New York: Fairchild

Kaiser SB. 2012. Fashion and Cultural Studies. New York: Berg

Kaiser SB, Nagasawa RH, Hutton SS. 1995. Construction of an SI theory of fashion: Part 1. Ambivalence and change. Cloth. Text. Res. 7. 13:172-83

Kant I. 1798. Anthropologie in pragmatischer Hinsicht. Leipzig: Verlag von Immanuel Müller

Kawamura Y. 2004. The Japanese Revolution in Paris Fashion. Oxford, UK: Berg

Kawamura Y. 2005. Fashion-ology: An Introduction to Fashion Studies. Oxford, UK: Berg 
Kawamura Y. 2006. Japanese teens as producers of street fashion. Curr. Sociol. 54:784-801

Kawamura Y. 2011. Doing Research in Fashion and Dress: An Introduction to Qualitative Methods. Oxford, UK: Berg

Kawamura Y. 2012. Fashioning Japanese Subcultures. London: Berg

Lieberson S. 2000. A Matter of Taste: How Names, Fashions, and Culture Change. Yale, CT: Yale Univ. Press

Lieberson S, Bell EO. 1992. Children's first names: an empirical study of social taste. Am. 7. Sociol. 98:511-54

Lipovetsky G. 1987 (1994). The Empire of Fashion: Dressing Modern Democracy. Princeton, NJ: Princeton Univ. Press. 276 pp.

Luhmann N. 1997. Die Gesellschaft der Gesellschaft. Frankfurt: Surhkamp

Luhmann N. 2000. The Reality of the Mass Media. Stanford, CA: Stanford Univ. Press

Mandeville B. 1714 (1924). The Fable of the Bees: Or Private Vices, Publick Benefits. New York: Penguin Class.

Manlow V. 2007. Designing Clothes: Culture and Organization of the Fashion Industry. New Brunswick, NJ: Transaction. $313 \mathrm{pp}$.

Marshall A. 1923. Money Credit and Commerce. London: Macmillan

McCracken G. 1989. Who is the celebrity endorser? Cultural foundations of the endorsement process. 7. Consum. Res. 16:310-21

McRobbie A. 1997. Bridging the gap: feminism, fashion and consumption. Fem. Rev. 55:73-89

Mears A. 2011. Pricing Beauty: The Making of a Fashion Model. Berkeley: Univ. Calif. Press

Mears A, Finlay W. 2005. Not just a paper doll: how models manage bodily capital and why they perform emotional labor. 7. Contemp. Ethnogr. 34:317-43

Moeran B. 2006. More than just a fashion magazine. Curr. Sociol. 54:725-44

Molotch HL. 2003. Where Stuff Comes From: How Toasters, Toilets, Cars, Computers, and Many Other Things Come to Be as They Are. New York: Routledge. 324 pp.

Nietzsche F. 1878 (1996). Human, All Too Human: A Book for Free Spirits. Transl. RJ Hollingdale. Cambridge, UK: Cambridge Univ. Press

Nystrom PH. 1928. Economics of Fashion. New York: Ronald Press

Pachucki MA, Breiger RL. 2010. Cultural holes: beyond relationality in social networks and culture. Annu. Rev. Sociol. 36:205-24

Paoletti JB. 1987. Clothing and gender in America: children's fashions, 1890-1920. Signs 13:136-43

Paulicelli E, Clark H, eds. 2009. The Fabric of Cultures: Fashion, Identity, and Globalization. New York: Routledge

Péretz H. 1992. Le vendeur, la vendeuse et leur cliente: ethnographie du prêt-à-porter de luxe. Rev. Fr. Sociol. $33: 49-72$

Pesendorfer W. 1995. Design innovation and fashion cycles. Am. Econ. Rev. 85:771-92

Pliny the Elder. ca. 77-79 (1952). Natural History, Volume IX, Books 33-35. Cambridge, MA: Loeb Class. Libr.

Polegato R, Wall M. 1980. Information seeking by fashion opinion leaders and followers. Home Econ. Res. 7 . 8:327-38

Postrel VI. 2004. The Substance of Style: How the Rise of Aesthetic Value Is Remaking Commerce, Culture, and Consciousness. New York: Perennial. 237 pp.

Power D, Hauge A. 2008. No man's brand-brands, institutions, fashion and the economy. Growth Change 39:123-43

Power D, Scott A, eds. 2004. The Cultural Industries and the Production of Culture. London: Routledge

Quemin A, Lévy C. 2011. Présentation: pour une sociologie de la mode et du vêtement. Sociol. Soc. 43:5-15

Rantisi NM. 2002a. The competitive foundations of localized learning and innovation: the case of women's garment production in New York City. Econ. Geogr. 78:441-62

Rantisi NM. 2002b. The local innovation system as a source of 'variety': openness and adaptability in New York City's garment district. Reg. Stud. 36:587-602

Raustiala K, Sprigman CJ. 2006. The piracy paradox: innovation and intellectual property in fashion design. Va. Law Rev. 92:1687-777

Robenstine C, Kelley E. 1981. Relating fashion change to social change: a methodological approach. Fam. Consum. Sci. Res. 7. 10:78-87

Rogers E. 1983. Diffusion of Innovation. New York: Free Press

Schmitz H, Knorringa P. 2000. Learning from global buyers. F. Dev. Stud. 37:177-205 
Segre Reinach S. 2006. Milan: the city of prêt-à-porter in a world of fast fashion. See Breward \& Gilbert 2006, pp. 123-35

Shen B, Wang Y, Lo CKY, Shum M. 2012. The impact of ethical fashion on consumer purchase behavior. 7. Fash. Mark. Manag. 16:234-45

Simmel G. 1904 (1957). Fashion. Am. 7. Sociol. 62:541-58

Skov L. 2006. The role of trade fairs in the global fashion business. Curr. Sociol. 54:764-83

Slater D. 1997. Consumer Culture and Modernity. Cambridge, UK: Polity

Smith A. 1759 (1982). The Theory of Moral Sentiments. Indianapolis, IN: Liberty

Solomon MR, Greenberg L. 1993. Setting the stage: collective selection in the stylistic context of commercials. 7. Advert. 22:11-23

Sombart W. 1916. Der moderne Kapitalismus. Historisch-systematische Darstellung des gesamteuropäischen Wirtschaftslebens von seinen Anfängen bis zur Gegenwart Endgültige, Zweiter Band. München/Leipzig: Verlag von Ducker \& Humblot

Sombart W. 2001. Economic Life in the Modern Age. New Brunswick, NJ: Transaction

Spencer H. 1897. The Principles of Sociology, Vol. II. New York: D. Appleton

Sproles GB. 1981. Analyzing fashion life cycles: principles and perspectives. F. Mark. 45:116-24

Sproles GB, Burns LD. 1994. Changing Appearances: Understanding Dress in Contemporary Society. New York: Fairchild. 323 pp.

Steele V. 1998a. A museum of fashion is more than a clothes-bag. Fash. Theory 2:327-35

Steele V. 1998b. Paris Fashion: A Cultural History. New York: Oxford Univ. Press. 327 pp.

Strang D, Macy MW. 2001. In search of excellence: fads, success stories, and adaptive emulation. Am. F. Sociol. 107:147-82

Svendsen L. 2006. Fashion: A Philosophy. London: Reaktion Books

Sweetman P. 1999. Anchoring the (postmodern) self? Body modification, fashion and identity. Body Soc. 5:5176

Tarde G. 1890 (1903). The Laws of Imitation. Transl. EC Parsons. New York: Henry Holt

Tokatli N. 2007. Global sourcing: insights from the global clothing industry—-the case of Zara, a fast fashion retailer. F. Econ. Geogr. 8:21-38

Tokatli N, Wrigley N, Kizilgün Ö. 2008. Shifting global supply networks and fast fashion: made in Turkey for Marks \& Spencer. Glob. Netw. 8:261-371

Tseëlon E. 2009. Fashion research and its discontents. Fash. Theory 5:435-51

Tulloch C. 2010. Style-fashion-dress: from black to post-black. Fash. Theory 14:361-86

Uzzi B. 1996. The sources and consequences of embeddedness for the economic performance of organizations: the network effect. Am. Sociol. Rev. 61:674-98

van Leeuwen T, Jewitt C, eds. 2001. Handbook of Visual Analysis. London: Sage

Veblen T. 1899. The Theory of the Leisure Class: An Economic Study of Institutions. New York: Dover Thrift. 244 pp.

Vinken B. 2005. Fashion Zeitgeist: Trends and Cycles in the Fashion System. New York: Berg

Volonté P. 2008. Vita da stilista. Il ruolo sociale del fashion designer. Milano: Bruno Mondadori

Watts DJ, Dodds PS. 2007. Influentials, networks, and public opinion formation. F. Consum. Res. 34:441-58

Weber M. 1958 (1991). From Max Weber: Essays in Sociology. London: Routledge. 490 pp.

Welters L, Lillethun A, eds. 2007. The Fashion Reader. Oxford, UK: Berg

Wenting R. 2008. Spinoff dynamics and the spatial formation of the fashion design industry, 1858-2005. 7. Econ. Geogr. 8:593-614

White HC. 2002. Markets from Networks: Socioeconomic Models of Production. Princeton, NJ: Princeton Univ. Press. xvii, 389 pp.

White HC, Godart FC, Corona VP. 2007. Mobilizing identities: uncertainty and control in strategy. Theor. Cult. Soc. 24:181-202

White N, Griffiths I. 2000. Introduction. In The Fashion Business: Theory, Practice, Image, ed. N White, I Griffiths, pp. 1-4. Oxford: Berg

Whitford J. 2006. The New Old Economy: Networks, Institutions, and the Organizational Transformation of American Manufacturing. New York: Oxford Univ. Press

Wilson E. 2003. Adorned in Dreams: Fashion and Modernity. London: Tauris

Zuckerman EW. 2012. Construction, concentration, and (dis)continuities in social valuations. Annu. Rev. Sociol. 38:223-45 


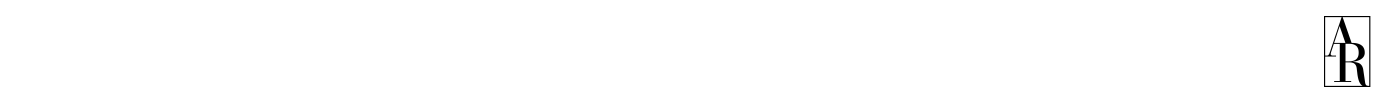

\section{Contents}

Annual Review of Sociology

Volume 39, 2013

Frontispiece

Charles Tilly ............................................................. xiv

\section{Prefatory Chapter}

Formations and Formalisms: Charles Tilly and the Paradox of the Actor Fobn Krinsky and Ann Mische 1

\section{Theory and Methods}

The Principles of Experimental Design and Their Application in Sociology Michelle fackson and D.R. Cox

The New Sociology of Morality Steven Hitlin and Stephen Vaisey

\section{Social Processes}

Social Scientific Inquiry Into Genocide and Mass Killing: From Unitary Outcome to Complex Processes Peter B. Owens, Yang Su, and David A. Snow

Interest-Oriented Action Lyn Spillman and Micbael Strand

Drugs, Violence, and the State Bryan R. Roberts and Yu Chen

Healthcare Systems in Comparative Perspective: Classification, Convergence, Institutions, Inequalities, and Five Missed Turns Jason Beckfield, Sigrun Olafsdottir, and Benjamin Sosnaud ...

\section{Institutions and Culture}

Multiculturalism and Immigration: A Contested Field in Cross-National Comparison Ruud Koopmans

Sociology of Fashion: Order and Change

Patrik Aspers and Frédéric Godart 
Religion, Nationalism, and Violence: An Integrated Approach

Philip S. Gorski and Gülay Türkmen-Dervişoğlu

\section{Formal Organizations}

Race, Religious Organizations, and Integration

Korie L. Edwards, Brad Christerson, and Michael O. Emerson

\section{Political and Economic Sociology}

An Environmental Sociology for the Twenty-First Century

David N. Pellow and Hollie Nyseth Brehm

Economic Institutions and the State: Insights from Economic History

Henning Hillmann

\section{Differentiation and Stratification}

Demographic Change and Parent-Child Relationships in Adulthood Fudith A. Seltzer and Suzanne M. Bianchi

\section{Individual and Society}

Gender and Crime

Candace Kruttschnitt

White-Collar Crime: A Review of Recent Developments and

Promising Directions for Future Research

Sally S. Simpson

From Social Structure to Gene Regulation, and Back: A Critical

Introduction to Environmental Epigenetics for Sociology

Hannab Landecker and Aaron Panofsky

Racial Formation in Perspective: Connecting Individuals, Institutions, and Power Relations

Aliya Saperstein, Andrew M. Penner, and Ryan Light

The Critical Sociology of Race and Sport: The First Fifty Years Ben Carrington

\section{Demography}

The Causal Effects of Father Absence

Sara McLanaban, Laura Tach, and Daniel Schneider

International Migration and Familial Change in Communities of Origin: Transformation and Resistance

Patricia Arias

Trends and Variation in Assortative Mating: Causes and Consequences Christine R. Schwartz 451 
Gender and International Migration: Contributions and Cross-Fertilizations

Gioconda Herrera

LGBT Sexuality and Families at the Start of the Twenty-First Century

Mignon R. Moore and Michael Stambolis-Rubstorfer

\section{Urban and Rural Community Sociology}

Housing: Commodity versus Right

Mary Pattillo

\section{Indexes}

Cumulative Index of Contributing Authors, Volumes 30-39 ..................... 533

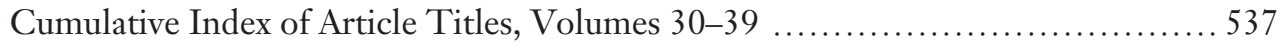

Errata

An online log of corrections to Annual Review of Sociology articles may be found at http://soc.annualreviews.org/errata.shtml 